\title{
Our Year of Assessment at Columbia University's Business and Economics Library
}

\author{
KATHLEEN DREYER and NISA BAKKALBASI \\ Columbia University, New York, New York, United States
}

\begin{abstract}
In order to establish a baseline understanding of the needs and the perceptions of service quality among graduate business and economics students and faculty, we employed a multi-method assessment approach combining quantitative and qualitative statistics through a survey, exit polls, and direct observations to inform improvement planning of library services and spaces.

While a substantial number of faculty and students were completely satisfied with the services and staff of the Thomas J. Watson Library of Business and Economics, there were some differences among student groups in terms of their satisfaction and interest in new services, technology, furniture, amount of space in the library, and service hours. The Watson Library is both a social and academic space, and students want to complete their academic work efficiently, without wasting time by switching locations, rooms, and/or devices. Our observation revealed that students rarely seem to engage in just one activity and are often studying, texting and talking with friends simultaneously.
\end{abstract}

\section{Introduction}

Libraries have changed rapidly in the last decade as librarians attempt to keep up with the ever-changing needs and demands of users. The diverse service needs of students and faculty in various disciplines makes this challenge even more daunting. In this climate of constant change, understanding how faculty and students become aware of and interact with new services and technologies is critical. A well-planned assessment can provide evidence that extends beyond anecdote, allowing library administrators and other interested parties to make informed decisions that better meet the needs of their academic community.
In the past decade, the interest in library assessment has expanded greatly particularly as a method to gather evidence and context for strategic planning and decision making. As has been the case with our counterparts across the nation, assessment of the quality and effectiveness of services and collections has grown exponentially at Columbia University Libraries. Over the past several years, the library staff at Columbia University has been collecting and analyzing an array of quantitative data, including card swipe access and interlibrary loan and circulation statistics, in an attempt to understand library visit patterns and collection use. Since 2003, Columbia University has administered

Kathleen Dreyer is the head of the Watson Library of Business and Economics at Columbia University, k.dreyer@columbia.edu. Nisa Bak.kalbasi is assessment coordinator for Columbia University Libraries, nisa.bakekalbasi@columbia.edu. 
campus-wide LibQUAL surveys, web-based instruments created and maintained by the Association of Research Libraries, to measure student and faculty perceptions of library service quality and to solicit feedback. While LibQUAL surveys have been useful in generating broad feedback on a wide range of library activities, they have provided few insights regarding the specific needs of graduate students and faculty in business and economics. Recognizing the differences in research and instruction practices across disciplines, we decided to implement an iterative assessment process to gain insight into the highly specialized needs of students and faculty of the School of Business and the Department of Economics. During the 20122013 academic year, Columbia University's Watson Library initiated the first iteration of its assessment process, targeting its core user population of graduate students and faculty in business and economics in order to gain insight into their needs. The rationale for our assessment is grounded in the Columbia University's Libraries' 2010-2013 strategic plan, specifically the plan's principles of research support and facilities improvement.

An important and useful way to begin the assessment process is by considering the context within which a library system functions and operates. Watson Library primarily supports the School of Business and the Department of Economics and is therefore mostly a graduate student library. However, students from across campus value Watson Library's central location, group study space, and open food and drink policy. This makes Watson Library a popular spot for those who prefer a lively atmosphere when they study either alone or with others. More than half a million visits to Watson
Library were recorded during the academic year 2011-2012, making it the second most frequented library on campus after Butler Library, which is the largest library on campus by both the number of seats and collection size.

In seeking to understand how our target groups view and use the space and services of Watson Library, it should be noted that MBA students in particular have expressed concerns about the library's facilities. These concerns are based on their perceptions of how and by whom the space is used. More specifically, business school students assert that there is not enough space for them in Watson Library, because they feel that there are too many undergraduates using the space. These concerns, in conjunction with our desire to better understand the needs of our users, led us to undertake these assessment projects, the results of which are discussed in this paper.

\section{Literature Review}

Despite the overall growth of academic library assessment (Kyrillidou \& Jaggars, 2013), to the best of our knowledge, almost nothing has been published on the use of library spaces and services by business and economics graduate students and faculty. Although one study targeted a population that is relevant to our assessment objectives the study focused on the information-seeking behavior of management and commerce faculty in Sri Lankan universities (Wickramanayake, 2010) -- the paper did not focus on the research behavior of users. However, there have been several studies with a broader focus on the needs of graduate students and faculty in a variety of disciplines. 
Berger and Hines (1994) found in their survey that four distinct user populations -undergraduates, graduate students, faculty, and university staff -- each used the library differently. Their research showed that graduate students behaved like a hybrid of undergraduates and faculty - like undergraduates they used the libraries for study space and like faculty they used the libraries for the collections and services (Berger \& Hines, 1994). More than a decade later, Kayongo and Helm (2009) surveyed graduate students to assess their use of services and collections. They found that graduate students tended not to ask librarians for research help and relied heavily on ecollections.

The library assessment team at the University of Chicago surveyed graduate students about their use of libraries and collections (Tatarka, Larsen, Olson, Schilt \& Twiss-Brooks, 2010). The results showed that students placed a greater emphasis on library study spaces, and their improvement, over services. Collections were also important, particularly the ease of access to resources (Tatarka, Larsen, Olson, Schilt \& TwissBrooks, 2010). It is important to note that the students of the Booth School of Business at the University of Chicago were underrepresented in the survey results due to low response rate.

At Oregon State University, librarians conducted focus groups to assess the needs of graduate students on campus. While students were generally happy with services and spaces, researchers discovered that some graduate students, particularly those in less well-funded departments, needed extra support and spaces for their teaching and research (Rempel, Hussong-Christian \& Mellinger, 2011).

In 2011, Georgetown University Libraries' graduate student assessment needs group conducted a survey and focus groups of graduate students who used a specific graduate library at Georgetown (Gibbs, Boettcher, Hollingsworth \& Slania, 2012). The first part of the study involved an online survey in which participants were asked about their perceptions of the library. The second part involved focus groups with subsets of the online survey participants. The researchers learned that students were generally happy with the services provided by the library staff but were dissatisfied with the quality and amount of study space in the library (Gibbs, Boettcher, Hollingsworth \& Slania, 2012).

The findings from Chicago, Oregon, and Georgetown were echoed in a joint study by the Cornell and Columbia Libraries (Gessner, Jaggars, Rutner and \& Tancheva, 2011), which focused on graduate students in the humanities. As the other studies found, $\mathrm{PhD}$ students who were interviewed for the study stated that they were generally happy with library collections but concerned about the type of space provided to them. They expressed a need for more space for individual study and a greater sense of community on campus (Gessner, Jaggars, Rutner and \& Tancheva, 2011).

In a seminal study, launched to understand how University of Rochester undergraduate students write research papers, Foster and Gibbons (2007) borrowed observation techniques from anthropologists. Using surveys, focus groups, and interviews, the study led the way for the use of 
anthropological techniques in studying students' behavior in libraries.

\section{Methodology}

In this study, we used a multi-method assessment approach, which combined quantitative and qualitative statistics and allowed comparison of outcomes across methods to tell the story of Watson Library. The development of the assessment plan began by establishing a clear and shared idea of goals we wanted to achieve. After a brainstorming session, the Watson Library staff defined their assessment objectives in specific and measurable terms:

1. To assess the degree to which students are satisfied with the library space;

2. To assess the degree to which students and faculty are satisfied with library services such as research help, circulation, course reserves, and technology equipment;

3. To assess the need for services not currently offered to faculty and students;

4. To understand how students use library spaces and to gain insight into their study habits.

Once the staff identified the objectives, the appropriate assessment methods became readily apparent. The assessment plan consisted of three parts:

1. Faculty and student survey to establish a baseline and understand perceptions of service quality;

2. Exit polls to learn what users are coming to the library to do;

3. Observation study to gain insight into students' study habits.

In the first part of the assessment, we used two locally developed online surveys, Faculty Service Quality Survey and Student Service
Quality Survey, which were distributed by the Head of Watson Library to all faculty and students in the School of Business and Department of Economics via email.

Data were collected between September 25, 2012 and October 12, 2012. There were 377 participants in the survey: 347 students and 30 faculty members. The overall response rate for the survey was 13\% for students and $6 \%$ for faculty; the response rate at the item level varied as noted in the findings. The survey respondents were a representative sample of MS, MBA, EMBA, and $\mathrm{PhD}$ students, and adjunct and full-time faculty in the School of Business and Department of Economics. Therefore, the findings derived from the survey results are representative of our users.

The second part of the assessment involved polling students as they were leaving Watson Library. Exit polls involved asking library visitors to write down their affiliation and what they came to the library to do on that day. The polls were conducted during a typical week (one that is neither unusually busy nor unusually slow) in the 2013 spring semester. Interns and library staff administered the polls during the week of March 4 on a Wednesday morning, Thursday late afternoon, and Saturday early afternoon, polling a total of 220 people.

In the third part of the assessment, we used direct and structured observations to capture structured data, thoughts, and ideas with minimal intrusiveness and modest resources. Three observers over three different time periods, 10 a.m., 3 p.m., and 8 p.m., conducted observations during a typical week, between Monday, April 1, 2013 and Sunday, April 7, 2013. Through use of a floor plan for each room included in the study, we 
Ticker: The Academic Business Librarianship Review, 1:1 (2015)

(C) 2015 Kathleen Dreyer and Nisa Bakkalbasi

employed codes (Table 1) to mark the activity

of each person occupying a user seat in the space. Overall, we coded a total of 3,290

library visitors during that week.
In addition, all observers were asked to stand or sit in one place to observe the space for five minutes at the end of the coding and make a few notes on their impression of the space.

Table 1: Codes for user activity

\begin{tabular}{ll}
\hline Code & Definition \\
\hline A & Reading and/or working on an academic assignment. \\
AL & Using own laptop/tablet/mobile device as part of academic work. \\
AC & Using library computer as part of academic work. \\
AG & Doing academic work as a group. \\
R & Socializing, resting and relaxing. \\
RG & Socializing, resting and relaxing as a group. \\
X & Not engaged (e.g., getting ready to leave or to sit down - not clear what he/she did or will be doing) \\
Z & Sleeping. \\
C & Camping (e.g., books, equipment, coat, bag occupy the user seat but there is no person in sight) \\
\hline
\end{tabular}

Codes in this study are adopted from Intermediate Workshop on Participatory Design in Academic Libraries, a workshop conducted by Nancy Foster at Washington University on Thursday, November 8, 2012.

\section{Results and Discussion}

\section{Student survey results}

The majority of students who participated in the survey were MBA students (282, 83\%), followed by Executive MBA (EMBA) students $(36,11 \%)$, and $\mathrm{PhD}$ students (24, $6 \%$ ). The majority of student respondents indicated that their academic area was Finance and Economics (137, 45\%), followed by Management (109, 35\%), Marketing (35, 11\%), Decision, Risk, and Operations (11, $3 \%)$, Economics (10, 3\%), and Accounting (6, $2 \%)$.

\section{Staff and services}

Overall, students were satisfied with research consultations provided by librarians and the general help available from library staff. Seventy-eight percent of students agreed or strongly agreed that library staff directed them to beneficial resources. One of the participants commented, "I have always had a favorable response from librarians. The service is fantastic and the resources and knowledge level of the staff are what one would expect from a school like [Columbia Business School]."

Table A1 in the appendix shows the ranking of survey items by average scores received from students from highest to lowest, with five being the highest possible score. There were some differences among student groups in terms of their satisfaction and interest in new services. The $\mathrm{PhD}$ students $(\mathrm{m}=4.67, \mathrm{n}=12)$ expressed a greater level of satisfaction with research help than MBA $(m=3.97, n=32)$ and EMBA $(m=4.00$, $\mathrm{n}=3$ ) students when agreeing with the statement, during my appointment with a librarian, he/ she belped me clarify things I did not understand. Additionally, $\mathrm{PhD}(\mathrm{m}=4.25, \mathrm{n}=24 ; \mathrm{m}=4.05$, $\mathrm{n}=19)$ and EMBA $(\mathrm{m}=4.32, \mathrm{n}=19 ; \mathrm{m}=3.79$, $\mathrm{n}=14$ ) students were more interested in receiving statistical support from library staff than MBA ( $m=3.39, \mathrm{n}=181 ; \mathrm{m}=3.17, \mathrm{n}=178$ ) students as displayed by respondent agreement with the statements, I wish that the 
Ticker: The Academic Business Librarianship Review, 1:1 (2015)

(C) 2015 Kathleen Dreyer and Nisa Bakkalbasi

library offered help using statistical software (e.g. Stata, SPSS, etc) and I wish that the library offered belp using and formatting data.

\section{Technology}

Students expressed dissatisfaction with technology and equipment in the library, which are managed and maintained jointly by the library and by the library's campus partners for information technology. Specifically, the average satisfaction levels for the statement, the technology (e.g., computers, software, etc.) in the library meets my needs indicated that MBA students $(m=3.09, n=259)$ were particularly dissatisfied in this area as compared to $\mathrm{PhD}$ students $(\mathrm{m}=4.05, \mathrm{n}=22)$ and EMBA students $(\mathrm{n}=3.32, \mathrm{n}=22)$.

However, not all of the equipment and technology in the library is maintained by the library. For example, some printers in the library are maintained by the Business School's Information Technology office. The survey did not include a question about wireless issues. The Columbia University Information Technology office manages the campus's wi-fi network, and the Business School Information Technology office manages the Business School's wi-fi network. Both networks are available in Watson Library. However, in the open-ended question, many students expressed frustration with the wireless connection in the library. One of the comments described the situation in a nutshell: "Well the wireless internet is still slow and interferes with my quickly studying." The high percentage $(53 \%)$ of no opinion responses for the statement, I use a mobile device (e.g. iPhone, tablet, etc.) to access library resources and services, might imply that students do not use mobile devices to access library resources and services.

\section{Space}

Although the majority of students felt that the services provided by staff met their needs, many participants reported that the study areas and library hours were insufficient, particularly due to overcrowding. Thirty-five percent of students disagreed or strongly disagreed that overall library space was conducive to studying and learning. One of the students commented, "Watson is overcrowded and the current policies are not ideal."

While the majority of students found that Watson Library is a good place for group study, $46 \%$ of students disagreed or strongly disagreed that the library was a good place for individual study. Another comment summarized some of the frustrations and suggestions expressed by the student participants: "Need more breakout rooms, later hours (post-9 p.m./post-midnight). Especially, need more quiet [sic], individual work/study areas like the 3rd floor. Too limited, and cannot get work done on the 1 st floor - it's a social hall, not a library. Not enough breakout rooms to compensate." The fact that Watson Library is designated as a group study space and can be a noisy library can explain such student sentiments. Users tend to work in groups on the same project or often many students, working on different assignments, sit together.

In addition, $37 \%$ of students reported that the library furniture was uncomfortable. In the open-ended feedback question, "Uncomfortable," "old," and "soiled," were just a few of the words students used, more than once, to describe the library furniture.

The differences among the student groups are illustrated in Table A1:

- $\mathrm{MBA}(\mathrm{m}=2.38, \mathrm{n}=263)$ and EMBA $(\mathrm{m}=2.67, \mathrm{n}=24)$ students were more 
Ticker: The Academic Business Librarianship Review, 1:1 (2015)

(C) 2015 Kathleen Dreyer and Nisa Bakkalbasi

dissatisfied with library furniture than $\mathrm{PhD}$ $(\mathrm{m}=3.61, \mathrm{n}=23)$ students. (I find the library furniture to be comfortable.)

- MBA students $(\mathrm{m}=2.93, \mathrm{n}=265)$ indicated that they had more difficulty finding a seat than $\mathrm{PhD}(\mathrm{m}=3.43, \mathrm{n}=23)$ students and EMBA $(\mathrm{m}=3.17, \mathrm{n}=23)$ students. ("T have been able to find a seat in the library on my visits.)

- MBA ( $\mathrm{m}=2.73, \mathrm{n}=264)$ students felt more strongly than $\mathrm{PhD}(\mathrm{m}=2.92, \mathrm{n}=24)$ students and EMBA $(\mathrm{m}=3.04, \mathrm{n}=24)$ students that the library was not a good place for individual study. (I find the library to be a good place for individual study.)
Most of the students disagreed that library hours met their needs. One of the students commented, "There are people who go to Butler Library after midnight because Watson closes at that time. I think Watson should be open till more late [sic]." Students reported that they need library hours to be extended significantly.

With respect to the open-ended feedback question, Table 2 displays the ranking of various pre-defined categories by total number of comments received. The highest number of comments received fell under the "Study Area" category.

Table 2: Summary of content analysis for the open-ended prompt, Please enter any comments about library services, staff, and facilities in the box below.

\begin{tabular}{lccccc}
\hline Pre-defined codes & Mixed & Negative & Neutral & Positive & Total \\
\hline Study area & 6 & 57 & 0 & 6 & 69 \\
Internet access & 3 & 31 & 0 & 2 & 36 \\
Printer/computer & 1 & 28 & 0 & 0 & 29 \\
Hours of service & 1 & 24 & 0 & 0 & 25 \\
Policy & 0 & 25 & 0 & 0 & 25 \\
Furniture & 1 & 20 & 0 & 1 & 22 \\
Office supplies & 0 & 22 & 0 & 0 & 22 \\
Other & 1 & 10 & 6 & 0 & 17 \\
Staff & 1 & 6 & 0 & 7 & 14 \\
Noise level & 2 & 11 & 0 & 0 & 13 \\
Temperature & 0 & 8 & 0 & 0 & 8 \\
\hline Total & $\mathbf{1 6}$ & $\mathbf{2 4 2}$ & $\mathbf{6}$ & $\mathbf{1 6}$ & $\mathbf{2 8 0}$ \\
\hline
\end{tabular}

\section{Faculty survey results}

Of faculty who participated in the survey, the majority were full-time faculty members $(23,77 \%)$ and the remaining participants were adjunct faculty. The majority of faculty members indicated that their academic department within the Business School was Finance and Economics (16, 49\%), followed by Accounting (7, 21\%), Marketing (5,15\%), Management (3, 9\%), Decision, Risk, and Operations (1, 3\%), and Economics (1, 3\%).

\section{Staff and services}

Overall, the faculty members reported higher satisfaction with library services and staff than students in general. Almost all faculty members agree or strongly agree that staff respond quickly to research questions and the help they receive is useful. Table A2 in the Appendix summarizes the ranking of survey items by average agreement scores received from faculty, from highest to lowest. Both fulltime $(\mathrm{m}=4.75, \mathrm{n}=12)$ and adjunct faculty $(\mathrm{m}=5.00, \mathrm{n}=4)$ reported high levels of 
satisfaction in response to the statement my appointment with a librarian, he/she helped me clarify things I did not understand. Both full-time $(\mathrm{m}=4.71, \mathrm{n}=17)$ and adjunct faculty $(\mathrm{m}=4.50$, $\mathrm{n}=4$ ) also expressed high satisfaction in response to the statement $I$ was directed to beneficial resources by staff. One of the participants commented, "I always find the library staff to be very helpful, knowledgeable and responsive. They do an excellent job." Unlike student respondents, who indicated that they need longer library hours, all faculty members agree or strongly agree that library hours meet their needs. One of the faculty members commented, "I have little need for a physical library. Access to electronic resources, both when I on campus and off is the single most important function."

Adjunct faculty expressed more interest in receiving help working with data and statistical software packages than full-time faculty. For example, the average item response score for the statement, I wish that the library offered help using and formatting data, was 1.6 points higher for adjunct faculty members $(m=4.6, n=5)$ than full-time faculty members $(\mathrm{m}=3.0$, $\mathrm{n}=14$ ). Also, the average item response score for the statement, I wish that the library offered belp using statistical software (e.g. Stata, SPSS, etc.), was 1.78 points higher for adjunct faculty $(\mathrm{m}=4.67$, $\mathrm{n}=6)$ than full-time faculty members $(\mathrm{m}=2.88$, $\mathrm{n}=17)$.

\section{Technology}

In reference to technology, equipment, and mobile device related statements, there were significant differences between adjunct faculty and full-time faculty average item response scores. In response to the statement, The technology (e.g., computers, software, etc.) in the library meets my needs, adjunct faculty $(\mathrm{m}=4.00, \mathrm{n}=5)$ feel less satisfied than full-time faculty $(\mathrm{m}=4.60, \mathrm{n}=10)$. This is also evident in the differences between adjunct $(m=3.60, n=5)$ and full-time faculty $(\mathrm{m}=4.38, \mathrm{n}=8)$ in response to the statement, There was an available computer terminal that I could use during my visit(s) to the library.

Full-time faculty appeared to be more interested than adjunct faculty in using mobile devices for their academic work and expressed interest in having more library resources and services available for tablets.

\section{Exit poll results}

The answers to the exit polls were informative and spoke to a good match between flexible library policy and user practice. The majority of the students polled $(119,54 \%)$ were from the Business School. Most of the students who participated in the exit poll said they came to the library to do homework, study for exams, and work with their groups. Other activities included checking email, eating, printing, tutoring, resting, and socializing with friends.

\section{Observation study results}

Our observations were consistent with survey results, which revealed that students believe that technology is important to academic success. Overall, we found that a significant number of people $(43 \%)$ were coded as working using their own laptop/tablet/mobile device. Another significant proportion $(33 \%)$ of Watson Library visitors was coded as working as a group, which was consistent with our survey findings that students expect the library to provide comfortable and readily available group study areas.

The observation study also included evidence that students make little use of the library-provided computers, other than the 
Bloomberg terminals. Watson Library has over twenty-five computers for student use, seven of which are dedicated to Bloomberg. More investigation needs to be done on why this is the case and whether having fewer computers would be worthwhile if it could free up some study space.

During our post-observation meeting, observers reported remarkable differences in the atmosphere of the library during different observation shifts. Mornings, particularly Friday, Saturday and Sunday, were very quiet and mellow. Weekday afternoons were very busy, making it the Watson Library's peak use period. Evenings tended to have a more relaxed feel than during the day. (See Table 3.)

Table 3: Number of observations by day and time

\begin{tabular}{lccc}
\hline & $\mathbf{1 0 : 0 0} \mathbf{a . m}$. & $\mathbf{3 : 0 0}$ p.m. & $\mathbf{8 : 0 0 ~ p . m . ~}$ \\
\hline Sunday & 18 & 236 & 131 \\
Monday & 117 & 329 & 186 \\
Tuesday & 87 & 264 & 194 \\
Wednesday & 120 & 298 & 165 \\
Thursday & 91 & 279 & 141 \\
Friday & 63 & 190 & 83 \\
Saturday & 13 & 181 & 104 \\
\hline Total & $\mathbf{5 0 9}$ & $\mathbf{1 , 7 7 7}$ & $\mathbf{1 , 0 0 4}$ \\
\hline
\end{tabular}

\section{Conclusions}

Following are the key findings from the study:

Overall, a substantial number of students are completely satisfied with the services and staff of the Watson Library.

- The students say that librarians are available for consultations when needed and are able to clarify things they do not understand. The library staff is excellent in all aspects of service- they are helpful, available, responsive, and knowledgeable.

- PhD students and EMBA students expressed interest in services regarding statistical support.
Students believe that technology is important to academic success, and they are frustrated with network connectivity and printers.

- Students want a fast and reliable wireless connection at all times. Students report that the Business School's wireless system has improved in the library this year as compared to the previous year, but it still performs well below expectations.

- Students report that printers often do not work and, when they do, they are very slow.

- When it comes to mobile technology, most of the students report that they use mobile devices in connection with their academic work, though a much smaller percentage of students report that they use mobile devices to access library resources and services. 
Students are dissatisfied with the furniture, amount of space in the library, and service hours of the facilities.

- Students want to complete their academic work efficiently, without wasting time by switching locations, rooms, and/or devices.

- Students report that they cannot find a seat in the library on their visit.

- Students expect the library to provide comfortable and readily available group study areas.

- The lack of quiet study space was also a frequent student complaint. While group study space remains important for business school students, quiet study space is also critical to their studies.

- Library hours need to be significantly extended to accommodate students' academic schedules. Students want the library to open an hour earlier and to remain open after midnight, especially during exam periods, and to extend summer hours to accommodate the EMBA summer schedule.

- Students report that furniture is old, dirty, uncomfortable, and inadequate.

Students rarely seem to engage in just one activity and often study, text, and talk with friends at the same time.

- Users tend to frequently switch between activities. While they may have their laptop and notes open for academic purposes, they were frequently observed switching among various activities including studying, texting and chatting with friends.

- Users are also using multiple devices in their work when they are working on their own or with others.

Overall faculty are very satisfied with the services and staff of Watson Library.
- The faculty appreciates the skills and knowledge of librarians; many stated that the librarians have been very helpful in addressing their research needs.

- Faculty agree with students that librarians are available for consultations and help clarify things they don't understand.

Adjunct faculty have different needs than tenure track faculty.

- These faculty would like help from the library staff in using and formatting data.

- They would also like assistance using statistical software.

- Adjunct faculty have a greater preference for accessing library resources via mobile devices.

The findings do not surprise us; we have known the shortcomings of library space as both anecdotal and hard evidence have suggested. Analysis of card swipe data shows that due to a very high number of library visitors in October, February, and April, Watson Library reaches maximum seating capacity on Monday, Tuesday, and Wednesday afternoons. The data are consistent with student comments, stating that they very often cannot find a seat in the library to study either individually or as a group. We understand the importance of managing the high expectations of business school and economics students and are aware that more needs to be done despite our serious space constraints.

\section{Actions}

Assessment projects should result in data that can be used to justify concrete actions. In this section we review the actions we took based on the assessment results and discuss plans for future projects. 
- Replaced old chairs in the reading room; to date we have replaced over 100 and will have replaced all reader chairs and soft seating by the end of summer 2015 .

- Renovated a small area of the library to add twenty-four new seats.

- Replaced the library printers and added three scanning stations.

- Worked with University IT and Business School IT to improve the wireless network in the library.

- Replaced the shades in the study rooms and refinished some of the tables in these rooms.

- Added tabletop outlets and USB ports to all tables in main reading room.

As stated earlier, Watson Library is mainly a group study space. The observation study showed that students take full advantage of the space by studying in groups or sitting together while working individually. Based on our observations, the library is both a social and academic space; this culture has been determined and maintained by those who use the space. We plan to continue observation studies systematically to capture data for comparison purposes.

In the future, it would be useful to conduct focus groups with EMBA and adjunct faculty to determine their exact needs with statistical software tools and training support.

The first iteration of our assessment plan was successful. This initial cycle has yielded useful results for improvements to the library services and spaces as well as deeper insights into user needs. The knowledge and information that we have gained through the assessment implementation process will be used to improve the assessment plan prior to the next cycle.

\section{References}

Berger, K. W., \& Hines, R. W. (1994). What does the user really want? The library user survey project at Duke University. Journal of Academic Librarianship, 20(5/6), 306.

Castro Gesner, G., Jaggars, D., Rutner, J. \& Tancheva, K. (2011). Supporting humanities doctoral student success: A collaborative project between Cornell University Library and Columbia University Libraries. Retrieved from http://www.clir.org/pubs/ruminations/ 02cornellcolumbia/report.html/report.pdf

Gibbons et al. (2007). Studying Students: The undergraduate research project at the University of Rochester. Retrieved from https://urresearch.rochester.edu/institutionalPu blicationPublicView.action?institutionalltemId= 7044\&versionNumber $=1$.

Gibbs, D., Boettcher, J., Hollingsworth, J. \& Slania, $\mathrm{H}$, (2012). Assessing the research needs of graduate students at Georgetown University. Joumal of Academic Librarianship, 38(5), 268 - 276.

Kayongo, J. \& Helm, C. (2009). Graduate students and the library: A survey of research practices and library use at the University of Notre Dame. Reference \& User Services Quarterly, 49(4), 341-349.

Kyrillidou, M.,\& Jaggars D. (2013) Current themes in academic library assessment: Select papers from the 2010 Watson Library Assessment Conference. Evidence Based Library and Information Practice, 8(2).

Rempel, H. G., Hussong-Christian, U., \& Mellinger, M. (2011). Graduate Student Space and Service Needs: A Recommendation for Cross-campus Solution. The Journal of Academic Librarianship, 37(6), 480-487. doi:10.1016/j.acalib.2011.07.004

Tatarka,A., Larsen,D., Olson, T., Schilt, M. \& TwissBrooks, A.(2010). Library survey 2010: Graduate and professional students. Retrieved from

http://www.lib.uchicago.edu/e/surveys/2010/ Lbrary $\% 20$ Survey $\% 202010 \% 20$ Full $\% 20$ Report .pdf

Wickramanayake, L. (2010). Information-seeking behavior of management and commerce faculty in Sri Lankan universities: An evaluation. Library Review, 59(8), 624-636. 


\section{APPENDIX}

Table A1: Descriptive statistics of student survey items, using a Likert scale to measure the extent to which a student agrees or disagrees with a statement from 1 (strongly disagree) to 5 (strongly agree)

\begin{tabular}{|c|c|c|c|c|c|c|c|c|c|c|c|c|}
\hline \multirow[t]{2}{*}{ Survey items } & \multicolumn{3}{|c|}{ PhD student } & \multicolumn{3}{|c|}{ MBA student } & \multicolumn{3}{|c|}{ EMBA student } & \multicolumn{3}{|c|}{ Overall } \\
\hline & Mean & S.D. & $\mathbf{N}$ & Mean & S.D. & $\mathbf{N}$ & Mean & S.D & $\mathbf{N}$ & Mean & S.D. & $\mathbf{N}$ \\
\hline $\begin{array}{l}\text { I was able to make an appointment with a librarian when I } \\
\text { needed to. }\end{array}$ & 4.64 & 0.67 & 11 & 4.04 & 0.75 & 24 & 4.33 & 0.58 & 3 & 4.24 & 0.75 & 38 \\
\hline I find the library to be a good place for group study. & 4.57 & 0.66 & 23 & 4.16 & 1.04 & 264 & 4.00 & 1.22 & 24 & 4.18 & 1.04 & 311 \\
\hline Help was available when I visited the library. & 4.52 & 0.60 & 21 & 4.13 & 0.80 & 205 & 4.14 & 0.73 & 21 & 4.17 & 0.78 & 247 \\
\hline $\begin{array}{l}\text { During my appointment with a librarian, he/she helped me } \\
\text { clarify things I did not understand. }\end{array}$ & 4.67 & 0.49 & 12 & 3.97 & 0.74 & 32 & 4.00 & 0.00 & 3 & 4.15 & 0.72 & 47 \\
\hline Staff respond quickly to my research questions. & 4.53 & 0.51 & 17 & 4.05 & 0.94 & 96 & 4.00 & 1.28 & 12 & 4.11 & 0.94 & 125 \\
\hline Help was available when I called the library. & 4.50 & 0.53 & 8 & 4.05 & 0.85 & 42 & 3.38 & 1.19 & 8 & 4.02 & 0.91 & 58 \\
\hline I use mobile devices in connection with my academic work. & 3.39 & 1.69 & 18 & 4.06 & 1.23 & 220 & 3.88 & 1.45 & 24 & 4.00 & 1.30 & 262 \\
\hline I was directed to beneficial resources by staff. & 4.39 & 0.61 & 18 & 3.89 & 0.91 & 129 & 3.86 & 1.10 & 14 & 3.94 & 0.91 & 161 \\
\hline $\begin{array}{l}\text { When I have a research question, the help I receive is } \\
\text { useful. }\end{array}$ & 4.41 & 0.71 & 17 & 3.83 & 0.91 & 114 & 4.08 & 1.12 & 13 & 3.92 & 0.92 & 144 \\
\hline I was able to easily access course reserve readings online. & 4.36 & 1.29 & 11 & 3.70 & 1.13 & 118 & 4.44 & 0.73 & 9 & 3.80 & 1.15 & 138 \\
\hline I am able to get the books I need. & 4.35 & 0.99 & 20 & 3.68 & 1.16 & 164 & 4.17 & 1.17 & 6 & 3.76 & 1.16 & 190 \\
\hline $\begin{array}{l}\text { I wish that more library resources and services were } \\
\text { available for tablets. }\end{array}$ & 3.47 & 1.55 & 15 & 3.73 & 1.30 & 138 & 4.06 & 1.24 & 16 & 3.74 & 1.32 & 169 \\
\hline $\begin{array}{l}\text { I wish that the library offered help using statistical } \\
\text { software (e.g. Stata, SPSS, etc). }\end{array}$ & 4.25 & 0.85 & 24 & 3.39 & 1.22 & 178 & 4.32 & 0.95 & 19 & 3.56 & 1.21 & 221 \\
\hline $\begin{array}{l}\text { The electronic resources that I needed were available } \\
\text { and/or working properly on my visit(s) to the library. }\end{array}$ & 4.10 & 0.83 & 21 & 3.48 & 1.16 & 233 & 3.62 & 1.53 & 21 & 3.53 & 1.18 & 275 \\
\hline $\begin{array}{l}\text { There was an available computer terminal that I could use } \\
\text { during my visit(s) to the library. }\end{array}$ & 4.18 & 0.85 & 22 & 3.43 & 1.22 & 237 & 3.61 & 1.38 & 18 & 3.50 & 1.22 & 277 \\
\hline
\end{tabular}




\begin{tabular}{|c|c|c|c|c|c|c|c|c|c|c|c|c|}
\hline \multirow[t]{2}{*}{ Survey items } & \multicolumn{3}{|c|}{ PhD student } & \multicolumn{3}{|c|}{ MBA student } & \multicolumn{3}{|c|}{ EMBA student } & \multicolumn{3}{|c|}{ Overall } \\
\hline & Mean & S.D. & $\mathbf{N}$ & Mean & S.D. & $\mathbf{N}$ & Mean & S.D. & $\mathbf{N}$ & Mean & S.D. & $\mathbf{N}$ \\
\hline $\begin{array}{l}\text { There were working printers for my use when I visited the } \\
\text { library. }\end{array}$ & 4.05 & 1.03 & 19 & 3.42 & 1.21 & 260 & 3.78 & 1.26 & 18 & 3.48 & 1.21 & 297 \\
\hline $\begin{array}{l}\text { I have been able to successfully use mobile technology } \\
\text { options to access library services (e.g., IM a Librarian, } \\
\text { renew a book, etc.) }\end{array}$ & 4.45 & 0.93 & 11 & 3.24 & 1.14 & 66 & 3.08 & 1.62 & 12 & 3.37 & 1.25 & 89 \\
\hline Library hours meet my needs. & 3.83 & 1.09 & 24 & 3.29 & 1.38 & 265 & 2.86 & 1.55 & 22 & 3.30 & 1.38 & 311 \\
\hline $\begin{array}{l}\text { I wish that the library offered help using and formatting } \\
\text { data. }\end{array}$ & 4.05 & 1.18 & 19 & 3.17 & 1.34 & 181 & 3.79 & 1.12 & 14 & 3.29 & 1.34 & 214 \\
\hline $\begin{array}{l}\text { The technology (e.g., computers, software, etc.) in the } \\
\text { library meets my needs. }\end{array}$ & 4.05 & 1.00 & 22 & 3.09 & 1.30 & 258 & 3.32 & 1.36 & 22 & 3.18 & 1.31 & 302 \\
\hline $\begin{array}{l}\text { The overall library space is conducive to studying and } \\
\text { learning. }\end{array}$ & 3.17 & 1.09 & 24 & 3.01 & 1.19 & 265 & 3.04 & 1.46 & 24 & 3.02 & 1.20 & 313 \\
\hline I have been able to find a seat in the library on my visits. & 3.43 & 0.99 & 23 & 2.93 & 1.19 & 265 & 3.17 & 1.37 & 23 & 2.98 & 1.20 & 311 \\
\hline $\begin{array}{l}\text { I use a mobile device (e.g. iPhone, tablet, etc.) to access } \\
\text { library resources and services. }\end{array}$ & 3.07 & 1.69 & 14 & 2.89 & 1.57 & 124 & 3.00 & 1.69 & 15 & 2.92 & 1.59 & 153 \\
\hline I find the library furniture to be comfortable. & 3.61 & 1.03 & 23 & 2.83 & 1.25 & 263 & 2.67 & 1.24 & 24 & 2.87 & 1.25 & 310 \\
\hline I find the library to be a good place for individual study. & 2.92 & 1.35 & 24 & 2.73 & 1.30 & 264 & 3.04 & 1.49 & 24 & 2.77 & 1.32 & 312 \\
\hline
\end{tabular}


Table A2: Descriptive statistics of faculty survey items, using a Likert scale to measure the extent to which a student agrees or disagrees with a statement from 1 (strongly disagree) to 5 (strongly agree)

\begin{tabular}{|c|c|c|c|c|c|c|c|c|c|}
\hline \multirow[t]{2}{*}{ Survey I tems } & \multicolumn{3}{|c|}{ Adjunct faculty } & \multicolumn{3}{|c|}{$\begin{array}{l}\text { Full-time } \\
\text { faculty }\end{array}$} & \multicolumn{3}{|l|}{ Total } \\
\hline & Mean & S.D. & $\mathbf{N}$ & Mean & S.D. & $\mathbf{N}$ & Mean & S.D. & $\mathbf{N}$ \\
\hline I was able to make an appointment with a librarian when I needed to. & 5.00 & 0.00 & 4 & 4.90 & 0.32 & 10 & 4.93 & 0.27 & 14 \\
\hline Staff respond quickly to my research questions. & 4.80 & 0.45 & 5 & 4.84 & 0.37 & 19 & 4.83 & 0.38 & 24 \\
\hline During my appointment with a librarian, he/she helped me darify things I did not understand. & 5.00 & 0.00 & 4 & 4.75 & 0.45 & 12 & 4.81 & 0.40 & 16 \\
\hline When I have a research question, the help I receive is useful. & 4.80 & 0.45 & 5 & 4.80 & 0.41 & 20 & 4.80 & 0.41 & 25 \\
\hline Library hours meet my needs. & 4.60 & 0.55 & 5 & 4.78 & 0.43 & 18 & 4.74 & 0.45 & 23 \\
\hline Help was available when I called the library. & 4.50 & 0.58 & 4 & 4.71 & 0.47 & 14 & 4.67 & 0.49 & 18 \\
\hline I was directed to beneficial resources by staff. & 4.50 & 1.00 & 4 & 4.71 & 0.59 & 17 & 4.67 & 0.66 & 21 \\
\hline $\begin{array}{l}\text { The electronic resources that I needed were available and/or working properly on } \\
\text { my visit(s) to the library. }\end{array}$ & 4.40 & 0.55 & 5 & 4.80 & 0.42 & 10 & 4.67 & 0.49 & 15 \\
\hline I am able to get the book I need. & 4.50 & 0.58 & 4 & 4.71 & 0.47 & 14 & 4.67 & 0.49 & 18 \\
\hline I was able to easily access course reserve readings online. & 4.67 & 0.58 & 3 & 4.50 & 0.58 & 4 & 4.57 & 0.53 & 7 \\
\hline Help was available when I visited the library. & 4.00 & 0.82 & 4 & 4.60 & 0.68 & 20 & 4.50 & 0.72 & 24 \\
\hline The technology (e.g., computers, software, etc.) in the library meets my needs. & 4.00 & 1.00 & 5 & 4.60 & 0.70 & 10 & 4.40 & 0.83 & 15 \\
\hline Course reserve readings were available for my students in a timely manner. & 4.80 & 0.45 & 5 & 3.80 & 0.92 & 10 & 4.13 & 0.92 & 15 \\
\hline I was able to easily request course readings be placed on reserve for my students. & 4.75 & 0.50 & 4 & 3.75 & 1.28 & 8 & 4.08 & 1.16 & 12 \\
\hline $\begin{array}{l}\text { There was an available computer terminal that I could use during my visit(s) to } \\
\text { the library. }\end{array}$ & 3.60 & 0.89 & 5 & 4.38 & 1.06 & 8 & 4.08 & 1.04 & 13 \\
\hline $\begin{array}{l}\text { I have been able to successfully use mobile technology options to access library } \\
\text { services (e.g., IM a Librarian, renew a book, etc.) }\end{array}$ & 4.33 & 0.58 & 3 & 3.67 & 1.53 & 3 & 4.00 & 1.10 & 6 \\
\hline I wish that more library resources and services were available for tablets. & 3.67 & 1.15 & 3 & 4.10 & 0.88 & 10 & 4.00 & 0.91 & 13 \\
\hline I use mobile devices in connection with my academic work. & 3.20 & 1.79 & 5 & 4.06 & 1.48 & 16 & 3.86 & 1.56 & 21 \\
\hline There were working printers for my use when I visited the library. & 3.50 & 0.71 & 2 & 4.00 & 1.15 & 4 & 3.83 & 0.98 & 6 \\
\hline I wish that the library offered help using and formatting data. & 4.60 & 0.89 & 5 & 3.00 & 1.62 & 14 & 3.42 & 1.61 & 19 \\
\hline I wish that the library staff would scan book chapters and articles for me. & 4.00 & 1.41 & 2 & 3.31 & 1.45 & 16 & 3.39 & 1.42 & 18 \\
\hline $\begin{array}{l}\text { I wish that the library offered help using statistical software (e.g. Stata, SPSS, } \\
\text { etc). }\end{array}$ & 4.67 & 0.82 & 6 & 2.88 & 1.54 & 17 & 3.35 & 1.58 & 23 \\
\hline I use a mobile device (e.g. iPhone, tablet, etc) to access library resources and services. & 3.33 & 2.08 & 3 & 3.17 & 2.04 & 6 & 3.22 & 1.92 & 9 \\
\hline
\end{tabular}

